\title{
DESIGN AND ASSESSMENT OF AN ASSIGNMENT-BASED CURRICULUM TO TEACH SCIENTIFIC WRITING AND SCIENTIFIC PEER REVIEW
}

\author{
Rainer E. Glaser \\ Department of Chemistry \\ University of Missouri \\ Columbia, Missouri 65211, U.S.A. \\ glaserr@missouri.edu
}

\begin{abstract}
A writing-intensive, upper-level undergraduate course which integrates content, context, collaboration, and communication in a unique fashion, is described. The topic of the seminar is "Scientific Writing in Chemistry" and an assignment-based curriculum was developed to instruct students on best practices in all aspects of science communication and to educate students about the scientific publication process and peer review. To effectively teach students how to understand science, both the content and the process must be included. Peer review is an integral and essential part of the process of science and the peer review tasks in the course described in this paper evolve from rubric-based peer assessments to free-format peer review. The curriculum was developed for a semester-long, three-hour seminar with limited enrolment. The curriculum was taught in the Spring semesters of 2010 - 2014 and enrolment data and results of evaluations collected over four years are presented to demonstrate the success of the implementations.
\end{abstract}

\section{Keywords}

Scientific writing, scientific peer review, curriculum design, assignment design, science communication, assessment

\section{Introduction}

Building on a century of general education policy (Boyer \& Levine, 1981), the National Science Foundation (NSF, 1996) recommended that STEM teachers: ... model good practices that increase learning; start with the student's experience, but have high expectations within a supportive climate; and build inquiry, a sense of wonder and the excitement of discovery, plus communication and teamwork, critical thinking, and life-long learning skills into learning experiences. (p. iv)

Within this learning framework, communication includes literacy (Robinson, McKenna, \& Conradi, 2011), which in the 21st century increasingly means scientific literacy (Pearson, Moje, \& Greenleaf, 2010). This requires an appreciation of the scientific process by the general public (Schwartz, 2007) as 
well as public engagement and effective science communication by scientists (Nisbet \& Scheufele, 2009).

We developed Chemistry is in the News (CIITN) to teach chemistry in the context of real-world issues and to expose students to all aspects of science communication. The CIITN activities consist of the study, creation and peer review of online projects based on news articles from the popular press. The activities aim to connect real-world social, economic and political issues to the learning of chemistry. The CIITN pedagogical framework (Carson, Hodgen, \& Glaser, 2006; Glaser \& Carson, 2005; Glaser \& Poole, 1999) and technical issues (Wu \& Glaser, 2004) of the implementation have been described and reviewed (Carson, Hume, Sui, Schelble, \& Glaser, 2009; Glaser, 2003, 2013), and results of evaluations (Carson \& Glaser, 2010; Hume, Carson, Hodgen, \& Glaser, 2006) have been reported. The entire CIITN peer review is conducted by students and includes an assessment framework for both individual and group assessment, rubrics to guide peer review and an intragroup peer review tool. CIITN was developed for large, lower-division (first and second year) university courses. CIITN has also been implemented in high schools in the United States.

Here, we report a more recent curriculum innovation which embraces the spirit and expands on the concepts of CIITN to educate upper-division (third and fourthyear) science majors about the scientific process, scientific writing, scientific peer review, and professional issues. The framework of an assignment-based curriculum of a writing-intensive, upper-division undergraduate seminar taught at the University of Missouri in Columbia (MU) is described. The rationale for the curriculum design is that not only should scientific content and method be understood by students but they should also experience peer review as an integral and essential part of the process of science (ARISE 2, 2013; Bennett, Gadlin, \& Levine-Finley, 2010; Coil, Wenderoth, Cunningham, \& Dirks, 2010). The seminar course Scientific Writing in Chemistry integrates content, context, collaboration and communication in a unique fashion and meets the criteria for writing-intensive courses of the University of Missouri's Campus Writing Program (2014). The curriculum was developed for a semester-long (14 weeks) course with three one-hour meetings per week and with limited enrolment. The curriculum was taught in the Spring semesters of 2010 - 2014 and results of evaluations for four years are presented.

While the curriculum has been developed for students at an American research university, the framework of the assignment-based approach is entirely transferable to other sciences and other educational levels and contexts. It is hoped that the present article will contribute to the wide dissemination of this curriculum. The curriculum described here is very much in the spirit of the Next Generation Science Standards (Achieve, 2013; Stage, Asturias, Cheuk, Daro, \& Hampton, 2013) and the report on integrated STEM education by the National Research Council (Honey, Pearson, \& Schweingruber, 2014). 


\section{Framework of the curriculum and course organisation}

The types and sequence of the assignments and the modes of their assessment by various forms of peer review constitute the framework of the curriculum. These remain essentially the same from one implementation to the next (Table 1).

Table 1

Course design: Content, software, and resources (2014)

\begin{tabular}{|c|c|c|c|c|c|c|}
\hline Focus & Week & Task & Points & $\begin{array}{l}\text { Peer } \\
\text { Review }\end{array}$ & Content & $\begin{array}{l}\text { Software and Online } \\
\text { Resources }\end{array}$ \\
\hline \multirow{9}{*}{ 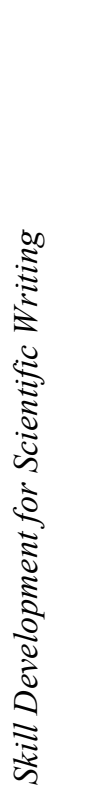 } & 1 & & & & $\begin{array}{l}\text { Reading Chemical } \\
\text { Literature, Publication } \\
\text { Types }\end{array}$ & $\begin{array}{l}\text { Browser, Portals: } \\
\text { ACS, Wiley-VCH, } \\
\text { RSC }\end{array}$ \\
\hline & 2 & A01 & 20 & $\mathrm{SR}^{1}$ & $\begin{array}{l}\text { Mindmapping \& } \\
\text { Outlining, Text }\end{array}$ & Word \\
\hline & 3 & A02 & 20 & $\mathrm{SR}^{1}$ & $\begin{array}{l}\text { Schemes; Integration of } \\
\text { Text \& Art }\end{array}$ & ChemDraw, Word \\
\hline & 4 & A03 & 20 & $\mathrm{SR}^{1}$ & $\begin{array}{l}\text { Tables, Statistics \& } \\
\text { Graphing }\end{array}$ & Excel \\
\hline & 5 & A04 & 20 & $\mathrm{SR}^{1}$ & Simulation \& Graphing & $\begin{array}{l}\text { Excel, Word, } \\
\text { ChemDraw, }\end{array}$ \\
\hline & 6 & A05 & 20 & $\mathrm{SR}^{1}$ & $\begin{array}{l}\text { Search, Citation \& } \\
\text { Bibliography }\end{array}$ & $\begin{array}{l}\text { SciFinder, Word, } \\
\text { ChemDraw }\end{array}$ \\
\hline & 7 & $\mathrm{~A} 06^{5}$ & 20 & & Oral Presentation & Powerpoint \\
\hline & 8 & & & $\mathrm{MR}^{2}$ & Oral Presentation Week & \\
\hline & 9 & A07 & 20 & $\mathrm{SR}^{1}$ & Structure and Modelling & Chem3D, Jmol etc. \\
\hline \multirow{5}{*}{ 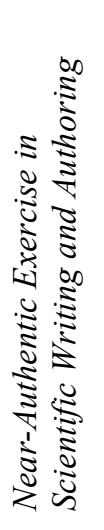 } & 10 & A08 & 20 & $\mathrm{SR}^{1}$ & $\begin{array}{l}\text { Writing I. Materials, } \\
\text { Methods, Appendix }\end{array}$ & $\begin{array}{l}\text { JOC Guidelines for } \\
\text { Authors }\end{array}$ \\
\hline & 11 & A09 & & $3 \mathrm{FFF}^{3}$ & $\begin{array}{l}\text { Writing II. Body \& } \\
\text { Abstract, Cover Letter }\end{array}$ & $\begin{array}{l}\text { Authentic Examples } \\
\text { provided }\end{array}$ \\
\hline & 12 & A10 & & & Scientific Peer Review & $\begin{array}{l}\text { Ethics Guidelines: } \\
\text { ACS and NAS }\end{array}$ \\
\hline & 13 & A11 & 40 & $3 \mathrm{FR}^{4}$ & $\begin{array}{l}\text { Revising \& Responding to } \\
\text { Peers, Graphical abstract }\end{array}$ & $\begin{array}{l}\text { Authentic Peer } \\
\text { Review Examples } \\
\text { provided }\end{array}$ \\
\hline & 14 & & & & $\begin{array}{l}\text { Scientific Conduct and } \\
\text { Misconduct }\end{array}$ & $\begin{array}{l}\text { PR-Cases \& ORI- } \\
\text { Resources }\end{array}$ \\
\hline
\end{tabular}

Notes to Table 1.

1. SR refers to single \& rubric-based peer review.

2. MR refers to multiple \& rubric-based peer review.

3. $3 F F F$ refers to three-fold free format peer review.

4. 3FR refers to three-fold rubric-based peer review.

5. In SP10, the oral presentation was "Project \#1" and it became A06 in subsequent implementations. Hence, A06 - A10 in SP10 correspond to A07 - A11 in later years. 
Each implementation of this framework presents a unique curriculum because all assignments are original with revised online resources and rubrics for assessment. In each semester, the assignments are connected to an overarching theme of the course:

- SP10 (Spring 2010): Aspirin and other Painkillers ${ }^{1}$;

- SP11 (Spring 2011): Dyes, Indicators and Chemical Sensors ${ }^{2}$;

- SP12 (Spring 2012): Soaps, Detergents and Ambiphiles ${ }^{3}$;

- SP13 (Spring 2013): Solar Energy ${ }^{4}$;

- SP14 (Spring 2014): Nutraceuticals: Sources, Delivery and Functions 5 .

All the assignments, associated data and sources, peer review devices and samples of completed assignments are available online and the URLs for the course web sites are provided as footnotes. The learning goals of the theme-based, researchoriented curriculum are well aligned with modern pedagogical principles. The framework of the curriculum emphasises crosscutting concepts (such as structure $\&$ function, pattern recognition, cause \& effect), informs about scientific practices and provides instruction about all aspects of actual research (National Academy of Engineering, 2010).

Writing a scientific research paper for a journal is very difficult and requires proficiency in many skills. Evidence suggests that it is most effective to move gradually from relatively simple tasks to more complex tasks in the writing process (Massengill, 2011; Topping, 2003). Because of this, more than half of the curriculum for this course is dedicated to Skill Development for Scientific Writing (A01 - A07, Table 1). After this preparation, the students engage in a NearAuthentic Exercise in Scientific Writing and Authoring (A08 - A11, Table 1).

In Assignments A01 - A04, students learn about outlining and organisation, about writing paragraphs, about the creation of schemes and figures, and about working with data (simple statistics and graphing). These assignments require the use of browser software, word-processing software, molecular structure drawing software, and spreadsheet software. Assignments A05 - A07 are more complex tasks with regard to content knowledge as well as process skills. Working on these assignments builds on the skills learned in A01 - A04 and also requires additional learning about literature and database access software, presentation software, and molecular display and modelling software. Moreover, the students need to raise their reading comprehension of primary literature, elevate their written communication skills, and they also need to learn the principles of, and demonstrate a proficiency in, persuasive oral presentations.

The incremental increase in the complexity of the tasks is reflected in the gradual increase in the students' autonomy regarding their selections of topic and sources.

\footnotetext{
${ }^{1} \mathrm{http}: / /$ faculty.missouri.edu/ glaserr/RG T SP10.html

${ }^{2} \mathrm{http} / / /$ faculty.missouri.edu/ glaserr/RG_T_SP11.html

${ }^{3} \mathrm{http}: / /$ faculty.missouri.edu/ glaserr/RG_T_SP12.html

${ }^{4} \mathrm{http} / / /$ faculty.missouri.edu/ glaserr/RG_T_SP13.html

${ }^{5} \mathrm{http}: / /$ faculty.missouri.edu/ glaserr/RG_T_SP14.html
} 
In assignments A01 - A04, the students work on common topics and they select literature from a provided pool of sources about the theme area. In Assignments A05 - A07, the students work on different topics and they select one topic from a provided pool of pre-selected topics within the theme area. Finally, in Assignments A08 - A11, the students work on different topics that they select freely from the primary literature covering the theme area and a pool of journals is provided to facilitate their access to the primary literature of theme area.

Thus, for Assignments A01 - A04, most of the data and literature are provided and the focus is on "working with data and sources" on a common topic. Assignments A01 and A02 introduce the theme of the course. The number of sources supplied for A01 and A02 and the mode of their provision has evolved from providing a small number of articles with the assignment (SP10 - SP12) to providing a much larger collection of articles on the theme of the course in the section "Science Topic Resources" on the course web site (since SP13). This evolution was made possible by the realisation that students are quite able to deal with a larger pool of sources if they are taught strategies to browse them for leading ideas.

In Assignments A03 and A04, students learn how to tabulate data, perform descriptive statistics, create histograms, and plot functions (A03) and to employ these skills for the reproduction of published spectra by sums of Gaussian functions (A04). All students work on the same data set for A03 to learn the basic skills and Assignment A04 is based on a recently published research article in the theme area of the course. With Assignments A05 and A06, the students take the step to "locating data and sources" about a topic of their choice selected from a list of possible topics within a defined theme.

Assignment A07 serves as an introduction to structure visualisation and molecular modeling and this assignment is built around a protein that plays a key role in the theme area of the course:

- SP10 (Spring 2010): COX-1 \& COX-2

- SP11 (Spring 2011): Green Fluorescent Protein

- SP12 (Spring 2012): Photosystems I \& II

- SP13 (Spring 2013): Subtilisin

- SP14 (Spring 2014): Superoxide Dismutase

While the topic of Assignment A07 is defined and the same for all students, the students need to write their assignments based on one article they select from a list of many "hits," and they must justify their choice to their peers.

For the Near-Authentic Exercise in Scientific Writing and Authoring (A08 - A11), the students enjoy great autonomy and select their topic freely from the primary literature covering the theme area. To facilitate the students' access to the primary literature, a list of specialised journals is included with A08 to provide some initial guidance. 


\section{Scheduling, collaboration and benefits of peer review}

The assignment-based curriculum requires students to work intensively on increasingly complex tasks during the semester. Several strategies have been employed to enable the students to live up to the high standards and to succeed in the course. Of course, the organisation must be explained with clearly stated deadlines so that the course remains on schedule.

The schedule is organised to a common "rhythm" (Figure 1). Work on assignments begins in Week 2 of the course, a new assignment starts every week, and work on each assignment is completed within two weeks. The students learn about context and background information pertinent to the assignment of the week in a lecture on Monday. The assignment is handed out (in hard copy) on Wednesday together with the rubric (also in hard copy) that will be used for the assessment of the assignment. The purpose of the assignment, the requirements with regard to content and formatting, and scheduling issues are clarified in conversation. On Fridays, the students meet in the computer laboratory and start working on their assignment. Technical issues are addressed either through minilectures by the instructor and/or a group of peer teaching assistants. Because of this schedule, the students become quite confident about the assignment by the end of the week; they understand the assignment, are clear about the purpose and the requirements and have learned all the skills required to complete the assignment on their own. Remaining questions can be addressed in class on Monday of the following week and the assignments are due the next day. The assignments are distributed for peer review on Wednesday and returned on Friday.

\begin{tabular}{llllll}
\hline Week & Day & Instruction Mode & A01 & A02 & A03 \\
\hline 2 & Mon & Lecture & Background & \\
\hline & Wed & Conversation & Assignment & \\
\hline 3 & Fri & Comp. Lab. & Work Task & & \\
\hline & Mon & Lecture & Questions? & Background & \\
\hline Wed & Conversation & Peer Review & Assignment & Background \\
\hline 4 & Fri & Comp. Lab. & Return PR & Work Task & Assignment \\
\hline \multicolumn{7}{c}{ Mon } & Lecture & & Questions? & Work Task \\
\hline 5 & Wed & Conversation & & Peer Review & Questions? \\
\hline \multirow{5}{*}{ Fri } & Mon & Comp. Lab. & & Return PR & Peer Review \\
\hline & Wed & Conversation & & Return PR \\
\hline
\end{tabular}

Figure 1. Course design: Sample organisation of assignment schedule 
Upper-division students might miss class meetings for legitimate reasons (e.g., illness, conference, interview, or athletics) and it can be difficult for students to negotiate the tight schedule of the curriculum throughout the semester. Therefore, it was decided that all activities in this course are to be performed by pairs of students. This stratagem has the immediate organisational benefit that every group can stay on schedule in spite of an occasional absence. Moreover, this stratagem also offers peer support (Carter, Cushing, \& Kennedy, 2008) and several pedagogical advantages (Barkley, Cross, \& Major, 2005; Hmelo-Silver, Chinn, Chan, \& O'Donnell, 2013). The curriculum of this course is challenging and it is unlike anything the students have been confronted with in previous courses both in content and format. The novelty of the curriculum and the relevance of the themes certainly contribute to the students' excitement about the course.

However, searching for and reading primary literature and working on researchoriented assignments may lead to some apprehension. We have found that working in pairs greatly helps the students to manage the demands of the course and to alleviate any doubts they might have as to whether they can succeed. Each pair of students works collaboratively on all the assignments and they receive the same score for their joint work. Working together on the assignments and on the peer reviews harvests the benefits of peer-to-peer learning (Rheingold, 2014; Vázquez et al., 2012) and especially promotes learning through collaborative argumentation (Chinn \& Clark, 2013).

\section{Assessment of assignments by various forms of peer review}

Peer review has been criticised because it frequently fails to catch errors and fraud, may favour articles that maintain the status quo, may introduce bias and prejudice to the publication process, and may be used for "turf protection" (Park, Peacey, \& Munafo, 2013; Watts, 1995; Ziman, 1968).Viewing peer review as merely a tool for quality control (Knoll, 1990; Rennie, 2003) might explain why peer review is largely absent from science education (Martyn, 2003). However, the objective of science is not just to acquire pieces of knowledge, rather its goal is a rational consensus over the widest possible field (Ziman, 1968) and the discourse leading to this goal therefore is the essence of science. As Ziman (1969, p. 324) explained, "It is not enough to observe, experiment, theorize, calculate and communicate; we must also argue, criticize, debate, and expound, summarize, and otherwise transform the information that we have obtained individually into reliable, well-established, public knowledge." Further, Habermas (1991) stressed the significance of establishing public knowledge through public debate. If laypeople in a society do not accept the products or procedures of the systems' sphere (science and technology), then the systems' sphere loses its authority and its discoveries become meaningless in the context of the wider society. Thus, the greatest meaning of the process of discourse is to make the information corporate and communal knowledge through debate and persuasion.

Most scientists have their first experience with peer review when they publish their first paper and receive peer review. For working scientists, however, both 
receiving and providing peer reviews are regular activities (Nicol, Thomson, \& Breslin, 2014). The curriculum design described here includes activities that exercise both directions of peer review in a gradually evolving fashion over the course of several months. We hold that a thorough development of peer review skills is intrinsically connected to the development of writing skills and argue that, in the absence of well-developed writing skills and some experience in scientific writing, one cannot judge the creative works of others "as a peer." It takes much knowledge (Yankulov \& Couto, 2012) and more than a briefing (Russell, 2013) to become proficient in scientific peer review. Peer review is much more than merely the ability to recognise substandard work and, therefore, peer reviewers should be able to appreciate the quality of original ideas. To build this capacity for constructive feedback on original works requires significant content expertise and writing practice. Meaningful curricula for science writing and peer review thus can be connected to laboratory courses (Walker \& Sampson, 2013) or to lecture courses with substantial (Carson \& Glaser, 2010; Hume et al., 2006) or intensive writing components.

Several forms of peer review are employed in this course (see Table 1). The peer review tasks evolve from rubric-based peer assessments to free-format peer review. At the same time, the peer review tasks evolve from assessments of the writer's technical and formal proficiencies and of the completeness of the assignment all the way to an assessment of the writer's capacities for excellence in topic selection, for logical organisation and sequencing, for the logical construction of arguments and their clear presentation, and for sound judgements in the formulation of conclusions. As an example, the rubric employed for Assignment A05 in the spring semester of 2014 is shown in Figure 2.

Scoring rubrics (ERIC, 2014; Panadero \& Jonsson, 2013; Reddy \& Andrade, 2010) include several criteria (dimensions) for the assessment and a rating scale for each criterion (levels). The expected performance for each level is described (descriptors) in an assessment grid. We employ a 4-level rating scale comprising "Beginning" (1), "Developing" (2), "Accomplished" (3), and "Exemplary" (4). The number of criteria varies. For example, Assignment A01 has 10 criteria; Assignments A02, A03, A05, A08 have 7; Assignments A06 and A11 have 6; Assignment A07 has 5; Assignment A04 has 4 criteria as more space is allowed for commentary (A10 is all free format). The types of criteria also gradually change from simple skill assessment early on to criteria for the assessment of higher-level issues. To define reasonable expectations and to set standards, samples of exemplary work by earlier cohorts of students (on assignments of the same types but on different topics) are posted on the course web site. All peer reviews are provided anonymously and the peer reviewers are not rewarded. 
Peer Review A05 by (author's names)

\begin{tabular}{|c|c|c|c|c|c|}
\hline & $\begin{array}{c}\text { Beginning } \\
1\end{array}$ & $\begin{array}{c}\text { Developing } \\
2\end{array}$ & $\begin{array}{c}\text { Accomplished } \\
3\end{array}$ & $\begin{array}{c}\text { Exemplary } \\
4\end{array}$ & Score \\
\hline $\begin{array}{l}\text { Identity, } \\
\text { structure, } \\
\text { uses, etc. }\end{array}$ & $\begin{array}{l}\text { Fewer than four } \\
\text { parts answered. }\end{array}$ & $\begin{array}{l}\text { Five parts } \\
\text { answered. IUPAC } \\
\text { name not reported } \\
\text { under problems } \\
\text { with one Scheme. }\end{array}$ & $\begin{array}{l}\text { Five parts answered. } \\
\text { Synonyms include } \\
\text { IUPAC name. } \\
\text { Schemes } 1 \& 2 \\
\text { present. }\end{array}$ & $\begin{array}{l}\text { Six parts answered. } \\
\text { Synonyms include } \\
\text { IUPAC name. } \\
\text { Schemes } 1 \& 2 \\
\text { excellent. }\end{array}$ & 14 \\
\hline $\begin{array}{l}\text { Experimenta } \\
\text { I section }\end{array}$ & $\begin{array}{l}\text { Lacking in scope, } \\
\text { content and } \\
\text { format. }\end{array}$ & $\begin{array}{l}\text { At least two } \\
\text { analytical } \\
\text { methods } \\
\text { incomplete and/or } \\
\text { incorrect data } \\
\text { sets. }\end{array}$ & $\begin{array}{l}\text { Three sets of } \\
\text { analytical data. } \\
\text { Complete and correct } \\
\text { data sets. Consistent } \\
\text { formatting. }\end{array}$ & $\begin{array}{l}\text { Four sets of } \\
\text { analytical data. } \\
\text { Complete and } \\
\text { correct data sets. } \\
\text { Flawless formatting. }\end{array}$ & 14 \\
\hline $\begin{array}{l}\text { Synthesis/Pr } \\
\text { ocessing }\end{array}$ & $\begin{array}{l}\text { Incomplete/incorr } \\
\text { ect structural } \\
\text { drawings; unclear } \\
\text { role of } \\
\text { compounds } \\
\text { drawn. }\end{array}$ & $\begin{array}{l}\text { Substrates and } \\
\text { products drawn, } \\
\text { but with some } \\
\text { errors. } \\
\text { Intermediates } \\
\text { and/or reagents } \\
\text { missing/incorrect. }\end{array}$ & $\begin{array}{l}\text { Substrates and } \\
\text { products drawn } \\
\text { correctly. Some } \\
\text { intermediates and/or } \\
\text { reagents } \\
\text { missing/incorrect. }\end{array}$ & $\begin{array}{l}\text { Substrates, } \\
\text { intermediates and } \\
\text { products drawn } \\
\text { correctly. Reagents } \\
\text { clearly specified }\end{array}$ & 14 \\
\hline $\begin{array}{l}\text { Art Citation } \\
\& \text { Caption } \\
\text { Counts } 0.5\end{array}$ & $\begin{array}{l}\text { Schemes/Figures } \\
\text { (S/F) are not cited } \\
\text { in the text. No S/F } \\
\text { captions in the } \\
\text { text. }\end{array}$ & $\begin{array}{l}\text { Some S/F are } \\
\text { cited in text. Every } \\
\text { S/F has a caption. } \\
\text { Caption formatting } \\
\text { needs revision. }\end{array}$ & $\begin{array}{l}\text { Most S/F are cited in } \\
\text { text. Every S/F has a } \\
\text { caption. Captions are } \\
\text { part of the text, } \\
\text { formatted well. }\end{array}$ & $\begin{array}{l}\text { All S/F are cited in } \\
\text { text. Every S/F has } \\
\text { a caption. Captions } \\
\text { are part of the text } \\
\text { and formatting is } \\
\text { flawless. }\end{array}$ & 12 \\
\hline $\begin{array}{l}\text { Ref. } \\
\text { Citations } \\
\text { Counts } 0.5\end{array}$ & $\begin{array}{l}\text { Some references } \\
\text { are cited, some } \\
\text { are not. Confused } \\
\text { about concepts } \\
\text { and/or } \\
\text { conventions. }\end{array}$ & $\begin{array}{l}\text { References are } \\
\text { cited. Placement } \\
\text { in text and/or } \\
\text { formatting needs } \\
\text { revision. }\end{array}$ & $\begin{array}{l}\text { All references are } \\
\text { cited using correct } \\
\text { format. Placement in } \\
\text { text is logical for most } \\
\text { references. }\end{array}$ & $\begin{array}{l}\text { All references are } \\
\text { cited using correct } \\
\text { format. Placement } \\
\text { in text is logical. }\end{array}$ & 12 \\
\hline $\begin{array}{l}\text { Bibliography } \\
\text { Counts } 0.5\end{array}$ & $\begin{array}{l}\text { Lacking in } \\
\text { substance, } \\
\text { content and } \\
\text { format. }\end{array}$ & $\begin{array}{l}\text { Appropriate } \\
\text { references cited. } \\
\text { Refs. Incomplete } \\
\text { and/or poorly } \\
\text { formatted. }\end{array}$ & $\begin{array}{l}\text { All but one of the } \\
\text { references are } \\
\text { complete. Formatting } \\
\text { is not perfect but } \\
\text { consistent. }\end{array}$ & $\begin{array}{l}\text { References are } \\
\text { complete and } \\
\text { formatting is } \\
\text { flawless. }\end{array}$ & 12 \\
\hline $\begin{array}{l}\text { Sections } \\
\text { Counts } 0.5\end{array}$ & $\begin{array}{l}\text { No idea about } \\
\text { sections. }\end{array}$ & $\begin{array}{l}\text { Sections present. } \\
\text { Problems with } \\
\text { placement of } \\
\text { references. }\end{array}$ & $\begin{array}{l}\text { Three sections. } \\
\text { Problems with } \\
\text { numbering of } \\
\text { references }\end{array}$ & $\begin{array}{l}\text { Three sections, } \\
\text { each on new page. } \\
\text { References follow } \\
\text { section, continuous } \\
\text { numbering. }\end{array}$ & 12 \\
\hline
\end{tabular}

Constructive comments to guide the Authors' Revision:

Figure 2. The rubric employed for the assessment of Assignment A05 in the spring semester of 2014. 
Rubric scoring is employed in the peer reviews of all assignments for Skill Development for Scientific Writing (A01 - A07) (see Table 1). In this phase, each assignment is assessed by single rubric-based peer review (SR) and the peer review is managed to ensure that each group reviews another group only once to minimise the consequence of overly positive or negative reviews. The oral presentations (A06) occur in three class meetings with 4-5 presentations per meeting. The presentations are assessed by multiple rubric-based peer review (MR) by the students in the audience (excluding all presenters and the co-chairs of the session) and the average score counts as the presenters' A06 score. With the rubric-based peer reviews given and received in A01 - A07, the students are well prepared for the Near-Authentic Exercise in Scientific Writing and Authoring and its three-fold, journal-style scientific peer review.

\section{Scientific writing \& peer review: Manuscript preparation, review and revision}

The overwhelming majority of scientific papers contain original data. Aspects related to the acquisition of the data are usually described in the Materials and Methods section and the data themselves are usually documented either in the paper or an Appendix or Supporting Information. An authentic exercise in scientific writing must be concerned with the rational analysis of original data within the existing context. However, there are obvious limitations to original data generation in writing classes and it is difficult for students to write a scientific paper without original data.

To resolve this conundrum, we ask the students to identify a suitable topic in the theme area, to collect all relevant information about a recently described molecule or material (structure, preparation, chemical characterisation, performance) and to adopt these data as their own. Hence, the students browse recent primary literature in search of a subject of their choice. A list of professional journals in the theme area is, however, provided for initial guidance. Each group is required to provide all sources about their molecule or material as a bibliography on the last page of the appendix of their paper.

With this premise, the sequence of Assignments A08 - A11 creates a nearauthentic experience in scientific writing and its assessment by scientific peer review. As the students select their topics, they create rough outlines of their papers (mindmaps, keywords, sketches of basic concept), mindful of the most important questions: What is the primary function of their material? How does the material accomplish its primary function? How well does the material perform the intended function? Which chemical and/or physical properties are not desired in such a material and why? The manuscript preparation is performed in Assignments A08 and A09.

Assignment A08 consists of: the selection of the subject, the collection of all the required information, and the documentation of experimental methods and results 
in the materials and methods section and in the appendix of the projected paper using the author guidelines from the Journal of Organic Chemistry (JOC). The students should report details about the preparation of the new material and data documenting the spectroscopic characterisation as Supporting Information. In the body of the paper, the students must write a summary of the preparation and focus on the quantification of the performance of the material. Experimental details of measurements of the material's primary function should be given in the Materials and Methods section and any data in support of the material's performance must be reported in the body of the paper. Assignment A08 is evaluated by rubric-based peer review to ensure that the groups are on track before they complete their papers for Assignment A09.

In Assignment A09 the sections, namely, Introduction, Results and Discussion, Conclusion, and Abstract are added to the product of A08. The students compare characteristic features of their material to two other prominent materials with the same function. With A09, the focus shifts from reporting and documenting to analysing, explaining, judging and concluding. In addition, with A09, the instruction on publication correspondence begins and the students need to write a cover letter to accompany the submission of the paper.

Each group writes a paper on the general theme of the course. However, the papers vary greatly because of the students' original selections of their specific topics. It is this commonality of the general theme together with the variety of the specific topics that ensures competent peer review. Hence, Assignments A10 and A11 truly provide instruction and practice in scientific peer review. Assignment A10 consists of the three-fold free-format scientific peer review (3FFF) of A09 submissions following the peer review format and criteria of JOC. In Assignment A11, the students respond to the peer reviews received. They revise their manuscripts, write rebuttal letters (i.e., cover letters that describe and justify all changes made), and submit these items for a second round of three-fold rubricbased (3FR) peer review by the previous three referees. This review of the revised papers is a rubric-based peer review and the average score of three reviews becomes the A11 score.

\section{Grading: Encourage high quality original submissions}

Initially (Spring semesters of 2010 - 2012, SP10-SP12), student course grades were based on their completion of all assignments in an "acceptable manner" (> $15 / 20$ points by peer review after revision). With growing confidence in the quality and fairness of the peer review process, the grading procedure was modified to increasingly reflect the peer review scores. Here we describe the grading scheme implemented since the Spring Semester 2013.

The peer review of an assignment results in a peer review score (PRS) up to a maximum of 20 points and the authors receive the PRS together with the rubric(s) completed by their peer reviewers. Various modes of revision are required depending on the peer review score of an original submission (PRSO). High 
quality original submissions are valued and rewarded during the Skill Development for Scientific Writing phase of the course. No revision is needed for a submission with PRSO $\geq 19$ ("Accepted as is"). Usually scores falls in the range $19>$ PRSO $\geq 15$ ("Minor revision required") and the students are asked to:

1. to read the peer review comments carefully

2. to revise their assignment considering the reviewer comments, and

3. to submit the revision in electronic form to the instructor with changes made with "tracking on."

The assignment is completed once the instructor accepts a satisfactory revision. Peer review scores PRSO < 15 ("Major revision required") are rarely given and, if they are, the students are asked to perform steps (1) - (3) and to complete an additional task, namely, to describe the changes made and explanations as to how the changes address the comments by the peer reviewers. The revision is accepted once it scores above 15 points.

In the Near-Authentic Exercise in Scientific Writing and Authoring phase of the course, again high quality original submissions of Assignment A08 are rewarded because all of the skills required for the execution of A08 have been acquired and practised in A01 - A07. However, the complete original paper is scored only after scientific peer review and revision, i.e. A11 is scored while A09 is not.

Course grades are based on the student's average of PRSO scores $(<\mathrm{PRSO}>)$ as follows: "A" if $<$ PRSO $>\geq 19$, "A-" if $<$ PRSO $>\geq 18$, "B+" if $<$ PRSO $>\geq 17$, and so on. In addition, students can improve their grades by: exemplary work (posted as sample, seven opportunities); an outstanding oral presentation (top three presentations); and/or an outstanding final paper (top three papers). Every instance of a special recognition improves the student's grade by one "notch." For example, a student with an average original peer review score of 17.5 and one submission selected for posting as a sample will receive an "A-".

The instructor shapes the outcome of the peer review by careful design of the assignments and the associated rubrics, by the provision of guidance, advice and feedback as the students work on their assignments, by discussion of posted exemplary samples from previous courses, and by the selection and recognition of exemplary submissions from the current course. However, to teach scientific peer review requires the instructor to create an atmosphere in which the students learn to trust the outcomes of peer review and, hence, it is important that the involvement of the instructor is minimised once the peer review process of the submissions proceeds. The instructor should only offer to mediate any disputes that might arise in the peer review.

\section{Results of evaluations}

\section{Informal evaluations}

Direct contact with the students in class and especially in the computer laboratory and the conversations with the peer teaching assistants in weekly meetings with 
the instructor provide continuous sources of formative feedback about all aspects of the course design and its implementation. Any concerns are identified and addressed in a timely manner and before significant problems can develop.

Toward the end of the course, the students are asked to list the ten most pertinent keywords they associate with the course. The frequency analysis of the collected keywords provides a "wordle" (Feinberg, 2013) as exemplified in Figure 3. "Writing," "Research," and "Chemistry" are usually the top three associations although their relative frequencies vary from semester to semester. The fourth most frequently occurring word usually has to do with the theme of the course (i.e., "Solar" in SP13).

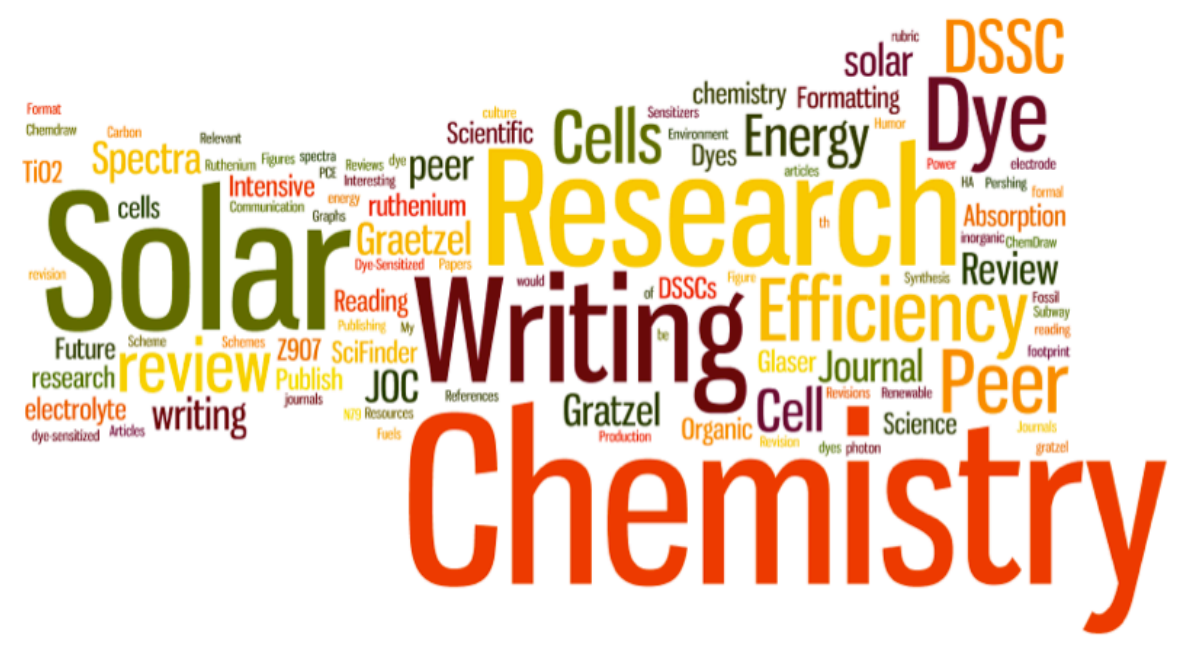

Figure 3. Wordle of the top-10 associations by the SP13 students at the end of the seminar "Scientific Writing in Chemistry" with the theme "Solar Energy." Font size reflects the frequency of the word.

This outcome of the free association exercise is nicely aligned with the intended learning goals. The course educates in scientific writing in chemistry and is research intensive. The themes of the courses facilitate these educational goals, and are selected to be sufficiently interesting and appealing to a general audience so that overly specialised chemistry content issues do not dominate the discourse. It also is noteworthy that some words occur only with low frequencies, and words associated with peer review fall into this category. Peer review is not a source of apprehension and, instead, the students accept and respect the peer review process.

\section{Formal evaluations}

The student's teaching evaluation involves a three-part questionnaire. Through legislation, Missouri (Spieler, 2007) requires students to rate their teachers on three "Consumer Information" criteria (Table 2) using a 4-level Likert scale ("strongly agree", "agree", "disagree", "strongly disagree") with 4 being the highest score. Students also may select "no opinion," The criteria are: 
1. The course content, including the lectures, syllabus, grading standards, and student responsibilities, was presented clearly.

2. The instructor was interested in student learning.

3. Considering both the possibilities and limitations of the subject matter and the course (including class size and facilities), the instructor taught effectively.

Table 2

Student Teaching Evaluations, Spring Semesters 2010 to 2013 (SP10-SP13) (on 4 point scale)

\begin{tabular}{lllll}
\hline Criteria of Evaluation & $\mathbf{S P 1 0}^{1}$ & $\mathbf{S P 1 1}^{2}$ & $\mathbf{S P 1 2}^{3}$ & $\mathbf{S P 1 3}^{4}$ \\
\hline Consumer Information, SB 389,\#1 & 3.56 & 3.67 & 3.72 & 3.79 \\
Consumer Information, SB 389, \#2 & 3.88 & 3.86 & 3.79 & 3.96 \\
Consumer Information, SB 389, \#3 & 3.56 & 3.38 & 3.66 & 3.58 \\
\hline
\end{tabular}

Notes to Table 2.

1. Spring 2010: http://faculty.missouri.edu/ glaserr/3700s10/3700s10_evals.html

2. Spring 2011: http://faculty.missouri.edu/ glaserr/3700s11/3700s11_evals.html

3. Spring 2012: http://faculty.missouri.edu/ glaserr/3700s12/3700s12_evals.html

4. Spring 2013: http://faculty.missouri.edu/ glaserr/3700s13/3700s13_evals.html

In addition, all students taking any course offered by MU's Department of Chemistry are asked to rate the teacher on the seven criteria listed in Table 3 using a 5-level Likert scale (4-0, 4 is high). The overall rating is determined as the average of the numerical scores of the seven department questions and this aggregate score is commonly used to measure teaching performance.

Table 3

Student Teaching Evaluations, Spring Semesters 2010 to 2013

\begin{tabular}{llllll}
\hline Criteria of Evaluation & SP10 $^{1}$ & SP11 $^{2}$ & SP12 $^{3}$ & SP13 $^{4}$ \\
\hline 1 & Organisation and preparation of lectures and discussions & 3.73 & 3.61 & 3.90 & 3.84 \\
2 & Instructor's enthusiasm for the subject matter & 3.96 & 3.96 & 4.00 & 3.96 \\
3 & Helpfulness in answering questions and clarifying points & 3.50 & 3.35 & 3.76 & 3.84 \\
4 & Ability to lecture in a manner which is easily followed & 3.46 & 3.52 & 3.76 & 3.72 \\
5 & Ability to stimulate interest in the subject & 3.07 & 3.22 & 2.97 & 3.72 \\
6 & Overall rating of the instructor & 3.69 & 3.57 & 3.66 & 3.88 \\
7 & Your rating of how much you have learned & 3.34 & 3.26 & 3.34 & 3.66 \\
8 & Overall rating, Average of Qs 1-7 & 3.53 & 3.50 & 3.63 & 3.80 \\
\hline
\end{tabular}

Notes to Table 3.

1. Spring 2010: http://faculty.missouri.edu/ glaserr/3700s10/3700s10_evals.html

2. Spring 2011: http://faculty.missouri.edu/ glaserr/3700s11/3700s11_evals.html

3. Spring 2012: http://faculty.missouri.edu/ glaserr/3700s12/3700s12_evals.html

4. Spring 2013: http://faculty.missouri.edu/ glaserr/3700s13/3700s13_evals.html 
In the third part of the questionnaire, the students are asked to respond to the following six questions:

1. List the strong and weak features of the lecturer and include suggestions for improvement.

2. Compare the lecturer to others you have had (especially with those in science courses at this level).

3. List the strong and weak features of the overall course (not the lecturer) and include suggestions on how its quality might be improved.

4. Compare the course with the others you have taken.

5. Your overall rating of the course (circle letter grade): A B C D E.

6. My approximate GPA prior to the current semester was

The students filled out the questionnaire toward the end of the semester and in the absence of the teacher. The teacher allocated $10-15$ minutes of class time for the students to fill out the questionnaires. Table 4 provides data on student numbers, completion rates for the evaluations and retention for the course.

Table 4

Student Teaching Evaluations, Spring Semesters 2010 to 2013

\begin{tabular}{lllll}
\hline Criteria of Evaluation & $\mathbf{S P 1 0}^{\mathbf{1}}$ & $\mathbf{S P 1 1}^{\mathbf{2}}$ & $\mathbf{S P 1 2}^{\mathbf{3}}$ & $\mathbf{S P 1 3}^{\mathbf{4}}$ \\
\hline Enrolment & 32 & 25 & 36 & 32 \\
Evaluations returned & 23 & 23 & 29 & 25 \\
Per cent of students returning evaluations & $72 \%$ & $92 \%$ & $81 \%$ & $78 \%$ \\
Student retention & $100 \%$ & $100 \%$ & $100 \%$ & $100 \%$ \\
\hline
\end{tabular}

The results of the teaching evaluations (average scores on Likert scale items) and transcripts of verbatim comments to the above questions became available to the teacher after all grades were filed. The author has made it a practice to post all of these data (average scores and complete student comments) online and freely accessible. The URLs are provided as notes to Tables 2 and 3 and selected student comments are listed in Tables 5 and 6.

The numerical results of evaluations show that the curriculum has enjoyed a high level of acceptance by the students every semester (Tables $2-4$ ). The increase of the overall rating may reflect the gradual refinements in the selection and delivery of the background material as well as the availability of a growing body of exemplary samples from earlier semesters.

Most importantly, the student commentaries (Tables 5 and 6) show that the curriculum is not only accepted but is welcomed and desired. In particular, the design of the peer review system has been succeeding very well (Table 6) with no more than 3 requests for the instructor to mediate peer review disputes in any given semester. 
Table 5

SP13 Students on Curriculum

\begin{tabular}{ll}
\hline Student & Student Comments \\
\hline S01: & It's a great course that offers loads of research experience. \\
S04: & It was unique, making it interesting. \\
S06: & Different but relatively effective. \\
S08: & One of the most interesting and challenging courses I have taken. I wish more \\
& classes were like this one. \\
S09: & Very interesting topics but lots of work! \\
S17: & Dr. Glaser chose a relevant and up and coming subject to study over the \\
& semester. Most professors teach from the book and don't relate it to what is \\
S18: & Velevant and important in today's society. \\
S19: & Different but really effective. \\
S21: & Learned how to research a lot better. I learned a lot on my own, not in class, \\
& but that may have been the goal of the class. \\
S22: & I learned a lot.
\end{tabular}

Table 6

SP13 Students on Peer Review

\begin{tabular}{ll}
\hline Student & Student Comments \\
\hline S16: & The assignments were reasonable but I wasn't [a] fan of the peer reviewing. \\
S18: & $\begin{array}{l}\text { Peer reviews [comments by fellow students, i.e., in A11] not always explained } \\
\text { in a way easy to follow. }\end{array}$ \\
S23: & $\begin{array}{l}\text { Peer review grading seems to be an issue, as some students choose to be more } \\
\text { rigorous than others. However, Dr. Glaser has a system for addressing issues. }\end{array}$ \\
S23: & \begin{tabular}{l} 
I think a group exercise in conducting peer-reviews would help. \\
\hline
\end{tabular}
\end{tabular}

\section{Conclusion}

We developed, implemented and assessed an assignment-based curriculum for a writing-intensive seminar called Scientific Writing in Chemistry to instruct students about all aspects of the scientific publication process and peer review. The course organisation, the scheduling of the assignment activities and the stratagem of requiring peer collaboration create an educational environment that harnesses the benefits of peer support and enables the students to work on research-oriented tasks. The learning goals of this curriculum are compelling and self-evident. We believe that the high level of acceptance reflects the clarity of the purpose of the curriculum.

The assignments start with simple tasks and evolve to more technically and intellectually challenging tasks and the principle of scaffolding is applied in various dimensions. The complexity of the writing tasks increases with regard to 
scope and integration of text and art. The other dimensions of scaffolded evolution include the levels of difficulty of the science content, the levels of working with primary sources, and the level of peer review proficiency.

The curriculum consists of a framework of assignments and this framework is defined by the types and sequence of the assignments and the modes of their assessment by peer review (Table 1). Every iteration of this framework is built around an overarching theme and, hence, every course presents a unique curriculum of original and connected assignments. The selection of a relevant and timely theme not only stimulates the students' interests, curiosity and motivation, but this novelty also ensures fresh and engaged instruction in every implementation. This curriculum is entirely transferable to other disciplines and we encourage the readers to implement similar courses on Scientific Writing in "your-discipline-here."

\section{Acknowledgements}

A summary of the curriculum appears in the proceedings of the 5th Eurovariety in Chemistry Education Conference, University of Limerick, Ireland, July 2013 and was published in Chemistry in Action! (Glaser, 2014). CIITN was supported by the Camille and Henry Dreyfus Foundation, MU and NSF.

The present work has been supported by the NSF-PRISM grant Mathematics and Life Sciences (MLS, \#0928053) and by a Faculty Development Award AY13/14 by MU's Campus Writing Program. We acknowledge continuing support and guidance by Marty Townsend, Amy Lannin, and Bonnie Selting. Part of this manuscript was written while the author was a Visiting Professor at the University of the Chinese Academy of Sciences (UCAS) and the Institute of Chemistry of the Chinese Academy of Sciences (ICCAS) in Beijing, China.

\section{References}

Achieve. (2013). Next Generation Science Standards (NGSS). Washington, DC: National Research Council. Retrieved from http://www.nextgenscience.org/next-generationscience-standards

ARISE 2 (Advancing Research in Science and Engineering). (2013). Unleashing America's research \& innovation enterprise. Cambridge, MA: American Academy of Arts and Sciences.

Barkley, E. F., Cross, K. P., \& Major, C. H. (2005). Collaborative learning techniques: A handbook for college faculty. New York: Jossey-Bass.

Bennett, L. M., Gadlin, H., \& Levine-Finley, S. (2010). Collaboration \& team science: A field guide. Bethesda, MD: National Institutes of Health.

Boyer, E. L., \& Levine, A. (1981). A quest for common learning-The aims of general education. Washington, DC: The Carnegie Foundation for the Advancement of Teaching.

Campus writing program. (2014). University of Missouri. Retrieved from http://cwp.missouri.edu 
Carson, K. M., Hodgen, B., \& Glaser, R. E. (2006). Teaching dissent and persuasion. Educational Research and Reviews, 1, 115-120. Retrieved from http://www.academicjournals.org/article/article1379590778_Carson\%20et\%20al.pdf

Carson, K. M., \& Glaser, R. E. (2010). Chemistry is in the news: Assessing intra-group peer review. Assessment and Evaluation in Higher Education, 34, 69-81. doi: $10.1080 / 02602930902862826$

Carson, K. M., Hume, D. L., Sui, Y., Schelble, S., \& Glaser, R. E. (2009). Chemistry is in the news: The why and wherefore of integrating popular news media into the chemistry classroom. In N. J. Pienta, M. M. Cooper, \& T. J. Greenbowe (Eds.), The Chemists' Guide to Effective Teaching, Vol. 2, Prentice Hall Series in Educational Innovation (pp. 230-245). Upper Saddle River, NJ: Prentice Hall.

Carter, E., Cushing, L., \& Kennedy, C. (2008). Peer support strategies for improving all students' social lives and learning. Baltimore, MD: Brookes Publishing.

Chinn, C. A., \& Clark, D. B. (2013). Learning through collaborative argumentation. In C. E. Hmelo-Silver, C. A. Chinn, C. K. K. Chan, \& A. M. O'Donnell (Eds.), The International Handbook of Collaborative Learning (pp. 314-332). New York: Routledge.

Coil, D., Wenderoth, M. P., Cunningham, M., \& Dirks, C. (2010). Teaching the process of science: Faculty perceptions and an effective methodology. CBE Life Sciences Education, 9, 524-535. doi: 10.1187/cbe.10-01-0005

ERIC, Institute of Education Sciences. Online bibliography on scoring rubrics. Retrieved from http://eric.ed.gov/?q=rubric

Feinberg, J. (n.d.). Wordle - Beautiful word clouds. Retrieved from http://www.wordle.net/

Glaser, R. E., \& Poole, M. J. (1999). Organic chemistry online: Building collaborative learning communities through electronic communication tools. Journal of Chemical Education, 76, 699-703. doi: 10.1021/ed076p699

Glaser, R. E. (2003). Science communication for all. Chemistry International, 25, 3-6. doi: $10.1515 /$ ci.2003.25.5.3

Glaser, R. E. (2013). Science communication for all. Chemistry in Action!, 99, 6-10.

Glaser, R. E. (2014). Teaching content, context, collaboration, and communication in college chemistry. Chemistry in Action!, 101, 10-19.

Glaser, R. E., \& Carson, K. M. (2005). Chemistry is in the news: Taxonomy of authentic news media based learning activities. International Journal of Science Education, 27, 1083-1098. doi: 10.1080/09500690500069434

Habermas, J. (1991). The structural transformation of the public sphere: An inquiry into a category of bourgeois society. Cambridge, MA: MIT Press.

Hmelo-Silver, C. E., Chinn, C. A., Chan, C., \& O’Donnell, A. M. (2013). The international handbook of collaborative learning (Educational psychology handbook). Routledge: New York, New York.

Honey, M., Pearson, G.; \& Schweingruber, H. (2014). STEM Integration in K-12 education: Status, prospects, and an agenda for research. Committee on Integrated STEM Education; National Academy of Engineering; National Research Council. 
Washington, DC: The National Academies Press. Retrieved from http://www.nap.edu/catalog.php?record_id=18612

Hume, D. L., Carson, K. M., Hodgen, B., \& Glaser, R. E. (2006). Chemistry is in the news: Assessment of student attitudes toward authentic news media based learning activities. Journal of Chemical Education, 83, 662-667. doi: 10.1021/ed083p662

Knoll, E. (1990). The communities of scientists and journal peer review. Journal of the American Medical Association, 263, 1330-1332. doi: 10.1001/jama.1990.03440100030004

Martyn, C. N. (2003). Peer review: Some questions from Socrates. In Godlee, F., \& Jefferson, T. (Eds.), Peer Review in Health Sciences (2nd ed., pp. 322-328). London: BMJ Books.

Massengill, R. P. (2011). Sociological writing as higher-level thinking: Assignments that cultivate the sociological imagination. Teaching Sociology, 39, 371-381. doi: $10.1177 / 0092055 X 11407350$

National Academy of Engineering and Committee on Standards for K-12 Engineering Education, National Research Council (NRC). (2010). K-12 Standards for Engineering Education? Washington, DC: National Academies Press.

National Science Foundation (NSF), Division of Undergraduate Education (1996). Shaping the Future: New Expectations for Undergraduate Education in Science, Mathematics, Engineering, and Technology. Arlington, VA: National Science Foundation. Retrieved from http://www.nsf.gov/pubs/stis1996/nsf96139/nsf96139.txt

Nicol, D., Thomson, A., \& Breslin, C. (2014). Rethinking feedback practices in higher education: A peer review perspective. Assessment and Evaluation in Higher Education, 39, 102-122. doi: 10.1080/02602938.2013.795518

Nisbet, M. C., \& Scheufele, D. (2009). What's next for science communication? Promising directions and lingering distractions. American Journal of Botany, 96, 1767-1778. doi: 10.3732/ajb.0900041

Panadero, E., \& Jonsson, A. (2013). The use of scoring rubrics for formative assessment purposes revisited: A review. Educational Research Review, 9, 129-144. doi: 10.1016/j.edurev.2013.01.002

Park, I.-U., Peacey, M., \& Munafo, M. R. (2014). Modelling the effects of subjective and objective decision making in scientific peer review. Nature, 506, 93-96. doi: 10.1038 /nature 12786

Pearson, P. D., Moje, E., \& Greenleaf, C. (2010). Literacy and science: Each in the service of the other. Science, 328, 459-463. doi: 10.1126/science.1182595

Rennie, D. (2003). Editorial peer review: Its development and rationale. In F. Godlee \& T. Jefferson (Eds.), Peer Review in Health Sciences (2nd ed., pp. 1-13). London: BMJ Books.

Reddy, Y. M., \& Andrade, H. (2010). A review of rubric use in higher education. Assessment and Evaluation in Higher Education 35, 435-448. doi: $10.1080 / 02602930902862859$

Rheingold, H. (2014). Peeragogy Handbook (2nd ed.). Jointly published by Pierce Press and PubDomEd. Retrieved from http://peeragogy.org 
Robinson, R. D., McKenna, M. C., \& Conradi, K. (2011). Issues and trends in literacy education (5th ed.). Upper Saddle River, NJ: Pearson.

Russell, A. A. (2013). The evolution of calibrated peer review. In T. Holme, M. M. Cooper, \& P. Varma-Nelson (Eds.), Trajectories of Chemistry Education Innovation and Reform (pp. 129-143). ACS Symposium Series. Washington, DC: American Chemical Society.

Schwartz, A. T. (2007). Chemistry education, science literacy, and the liberal arts. 2007 George C. Pimentel Award. Journal of Chemical Education, 84, 1750-1755. doi: $10.1021 /$ ed084p1750

Spieler, T. L. (2007). Missouri SENATE BILL NO. 389. Retrieved from http://www.senate.mo.gov/07info/pdf-bill/intro/SB389.pdf

Stage, E. K., Asturias, H., Cheuk, T., Daro, P. A., \& Hampton, S. B. (2013). Opportunities and challenges in next generation standards. Science, 340, 276-277. doi: 10.1126/science. 1234011

Topping, K. (2003). Self and peer assessment in school and university: Reliability, validity and utility. In M. Segers, F. Dochy, \& E. Cascallar (Eds.), Optimizing New Modes of Assessment: In Search of Qualities and Standards (pp. 55-87). Dordrecht, The Netherlands: Kluwer.

Vázquez, A. V., McLoughlin, K., Sabbagh, M., Runkle, A. C., Simon, J., Coppola, B. P., \& Pazicni, S. (2012). Writing-to-teach: A new pedagogical approach to elicit explanative writing from undergraduate chemistry students. Journal of Chemical Education, 89, 1025-1031. doi: 10.1021/ed200410k

Walker, J. P., \& Sampson, V. (2013). Argument-driven inquiry: Using the laboratory to improve undergraduates' science writing skills through meaningful science writing, peer-review, and revision. Journal of Chemical Education, 90, 1269-1274. doi: $10.1021 / \mathrm{ed} 300656 \mathrm{p}$

Watts, C. (1995). From collegial to codified. The evolution of modern peer review. Texas Medicine, 91, 22-24.

Wu, Z., \& Glaser, R. E. (2004). Software for the synergistic integration of science with ICT education. Journal of Information Technology Education: Research, 3, 325-339.

Yankulov, K., \& Couto, R. (2012). Peer review in class: Metrics and variations in a senior course. Biochemistry and Molecular Biology Education, 40, 161-168. doi: 10.1002/bmb.20592

Ziman, J.M. (1968). Public knowledge: An essay concerning the social dimension of science. London, UK: Cambridge University Press.

Ziman, J.M. (1969). Information, communication, knowledge. Nature, 224, 318-324. doi: $10.1038 / 224318 \mathrm{a} 0$

Copyright @ 2014 Rainer E. Glaser 